\title{
Biosynthesis of Lysine in Saccharomyces cerevisiae: Regulation of Homocitrate Synthase in Analogue-Resistant Mutants
}

\author{
By GARY S. GRAY AND J. K. BHATTACHARJEE \\ Department of Microbiology, Miami University, Oxford, Ohio 45056, U.S.A.
}

(Received I5 May 1976; revised I July 1976)

\section{INTRODUCTION}

Homocitrate synthase (EC. 4.I.3.2I), the first enzyme of the 2-aminoadipic acid pathway for biosynthesis of lysine, is feedback inhibited and repressed by L-lysine in Neurospora crassa (Hogg \& Broquist, 1968). There are two homocitrate synthases in Saccharomyces cerevisiae; both of them are feedback inhibited by L-lysine, but only one is repressed by L-lysine (Tucci \& Ceci, 1972). 5-Hydroxy-DL-lysine (DL-hydroxylysine) inhibits the growth of wild-type $S$. cerevisiae, and the enzymes of lysine biosynthesis are non-coordinately repressed by L-lysine or DL-hydroxylysine (Sinha, Kurtz \& Bhattacharjee, 197I). This paper compares the regulation of homocitrate synthase and the excretion of lysine from the wild-type strain and from mutant strains of $S$. cerevisiae resistant to the analogues of lysine, DL-hydroxylysine and to $S$-(3-aminoethyl)-L-cysteine (L-thialysine).

\section{METHODS}

Organisms and growth conditions. Thialysine-resistant strain AEC-RI, hydroxylysineresistant strain OHL-I A, lysine auxotroph 46952 (lysI3), and wild-type S. cerevisiae (X2I 80) were used. Stock cultures were maintained on a complete medium containing: glucose, $20 \mathrm{~g}$; $\mathrm{MgSO}_{4} \cdot 7 \mathrm{H}_{2} \mathrm{O}$, I g; $\mathrm{KH}_{2} \mathrm{PO}_{4}, 2 \mathrm{~g}$; peptone, $6 \mathrm{~g}$; yeast extract, $4 \mathrm{~g}$; agar, $25 \mathrm{~g}$; distilled water, $\mathrm{I} 1$. The $\mathrm{pH}$ value was adjusted to 5.5 and the medium was sterilized by autoclaving for $\mathrm{I} 5 \mathrm{~min}$ at $\mathrm{I} 2 \mathrm{I}{ }^{\circ} \mathrm{C}$. Cells for growth studies and enzyme preparations were grown in shaken cultures at $30^{\circ} \mathrm{C}$ in minimal medium containing: Difco yeast nitrogen base without amino acids, $6.7 \mathrm{~g}$; glucose, Io g; distilled water, I 1 . This medium was supplemented with L-lysine or an analogue of lysine as required.

Enzyme preparation. Cells from the late-exponential growth phase were disrupted with a Bronwill MSK homogenizer (Bronwill Scientific Co., San Mateo, California, U.S.A.). Homogenates were centrifuged at $14000 \mathrm{~g}$ at I ${ }^{\circ} \mathrm{C}$ for $20 \mathrm{~min}$ and the supernatant solutions were dialysed against $\mathrm{I} 00$ vols $0.02 \mathrm{M}$-Tris/ $\mathrm{HCl}$ buffer $\mathrm{pH} 8.0$ at $8{ }^{\circ} \mathrm{C}$ for $\mathrm{I} 6 \mathrm{~h}$ with three changes of buffer. Dialysed extracts were used as the source of enzyme (Sinha \& Bhattacharjee, 1970). Protein content was determined by the biuret method using crystalline bovine serum albumin as a standard (Gornall, Bardawill \& David, 1949).

Measurement of homocitrate synthase. The method was based on that described by Wieland, Weiss \& Eger-Neufeldt (I964) for citrate synthase except that oxaloacetate was substituted by 2-oxoglutarate. The reaction mixture contained (in I ml): 2-oxoglutarate, I00 $\mu \mathrm{M}$; acetyl-CoA, $35 \mu \mathrm{M} ; 2,6$-dichlorophenolindophenol, $35 \mu \mathrm{M}$; Tris/HCl buffer $\mathrm{pH} 8.0$, IOO mM; and dialysed extract equivalent to I mg protein. These concentrations of substrates gave maximum activity. The reaction was initiated by adding the enzyme. Where applicable, potential inhibitors were added to the reaction mixture before adding the enzyme. The 2-oxoglutarate-dependent cleavage of acetyl-CoA and the subsequent reduction 
of 2,6-dichlorophenolindophenol was measured spectrophotometrically at $600 \mathrm{~nm}$ using a recording spectrophotometer. Activity was expressed as nmol product formed $\mathrm{min}^{-1}$ (mg protein) $)^{-1}$.

Isolation of analogue-resistant mutants. Wild-type strain X2180 was inoculated into minimal medium supplemented with $10^{-3} \mathrm{M} L$-thialysine or DL-hydroxylysine. Growth occurred after 5 to 6 days of shaking at $30^{\circ} \mathrm{C}$. The cells were then diluted and plated on to minimal agar medium and subsequently replica-plated on to minimal medium supplemented with $\mathrm{IO}^{-3} \mathrm{M}$ L-thialysine or DL-hydroxylysine. Representative colonies capable of growth after $24 \mathrm{~h}$ in medium supplemented with the appropriate analogue were selected as thialysine-resistant (AEC-RI) or hydroxylysine-resistant (OHL-IA) mutants.

Lysine excretion. Three Erlenmeyer flasks, each containing $48 \mathrm{ml}$ minimal medium supplemented with $5 \mu \mathrm{Ci}$ of DL-2-amino[ $\left[{ }^{-14} \mathrm{C}\right]$ adipic acid $\left(20 \mathrm{mCi} \mathrm{mmol}{ }^{-1}\right)$, were inoculated with $2 \mathrm{ml}$ starter culture of strains X2180, AEC-RI and OHL-IA, respectively. Radioactivity from 2-amino[ $\left[{ }^{14} \mathrm{C}\right]$ adipic acid is selectively incorporated into lysine (Bhattacharjee \& Tucci, 1969). Flasks were shaken at $30{ }^{\circ} \mathrm{C}$ for $48 \mathrm{~h}$. Cells were harvested by centrifuging and washed by resuspension in $5 \mathrm{ml}$ cold distilled water followed by centrifuging. The washings were combined with the respective supernatant solutions and lyophilized; this was the 'extracellular fraction'. Washing with cold distilled water did not impair the intracellular pool of lysine. The washed cells were resuspended in $10 \mathrm{ml}$ distilled water, heated in a boiling water bath for $30 \mathrm{~min}$, and centrifuged; the supernatant solution was the "intracellular fraction'. Intracellular and extracellular fractions were analysed chromatographically to determine radioactive lysine and 2-aminoadipic acid (Kurtz \& Bhattacharjee, 1975).

Chemicals. DL-2-Amino[I $\left.{ }^{14} \mathrm{C}\right]$ adipic acid was obtained from The Radiochemical Centre, Amersham. All other fine chemicals, including L-thialysine and DL-hydroxylysine, were obtained from Sigma.

\section{RESULTS AND DISCUSSION}

L-Thialysine and DL-hydroxylysine $\left(\mathrm{IO}^{-3} \mathrm{M}\right)$ inhibited growth of wild-type strain X2180 for 3 to 4 days. The inhibition was reversed by $10^{-3} \mathrm{M}$ L-lysine. Feedback sensitivity of homocitrate synthese activity in extracts of X2180 was examined (Table I). L-Lysine and Lthialysine, and to a lesser extent DL-hydroxylysine, decreased the synthase activity. The enzyme was also inhibited by $10^{-2} \mathrm{M} \mathrm{L}$-arginine, L-norleucine and L-norvaline (Table I), but not by $\mathrm{IO}^{-2} \mathrm{M}-2$-aminoadipic acid (an intermediate of the lysine biosynthetic pathway) or by

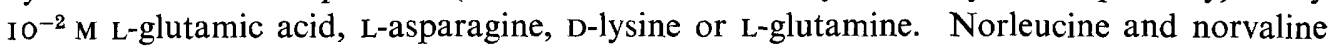
also inhibit saccharopine dehydrogenase which catalyses the last reaction of lysine biosynthesis (Fujioka \& Nakatani, I972).

Homocitrate synthase activity in extracts of analogue-resistant strains AEC-RI and OHL-I A was less sensitive than the wild-type enzyme to feedback inhibition by L-lysine, $L$-thialysine, and slightly less resistant to inhibition by DL-hydroxylysine (Table I). The activity in strain AEC-RI was also resistant to inhibition by $10^{-2} \mathrm{M}$ L-norleucine and L-norvaline; $10^{-2} \mathrm{M}$ $\mathrm{L}$-arginine gave only $25 \%$ inhibition of the enzyme from this strain.

The possibility of increased lysine production by AEC-RI and OHL-IA compared with $\mathrm{X} 2 \mathrm{I} 80$ was investigated in experiments using $\mathrm{DL}-2$-amino $\left[\mathrm{I}-{ }^{14} \mathrm{C}\right]$ adipic acid as substrate (Table 2). Strain AEC-RI accumulated almost four times as much extracellular lysine as did X2180, but only a slight increase of extracellular lysine was seen with OHL-I A. The intracellular concentrations of lysine and 2-aminoadipic acid were greatly reduced in strain AEC-RI compared with X2180 and OHL-IA. Total non-protein lysine (intracellular plus extracellular) from AEC-RI was more than $250 \%$ that of X2180. The concentration of extracellular 2-amino- 
Table I. Feedback inhibition of homocitrate synthase activity from wild-type (x2 I 80), thialysine-resistant (AEC-RI) and hydroxylysine-resistant (OHL-IA) strains of S. cerevisiae

Extracts were prepared and the homocitrate synthase activity was determined as described in Methods.

\begin{tabular}{|c|c|c|c|c|}
\hline \multirow[b]{2}{*}{ Inhibitor } & \multirow[b]{2}{*}{ Concn (mM) } & \multicolumn{3}{|c|}{$\begin{array}{c}\text { Homocitrate synthase activity } \\
\text { [nmol product formed } \text { min }^{-1}\left(\text { mg protein }^{-1}\right]\end{array}$} \\
\hline & & $\mathrm{X} 2 \mathrm{I} 80$ & AEC-R I & OHL-I A \\
\hline None & & $0 \cdot 280$ & 0.280 & 0.280 \\
\hline L-Lysine & $\begin{array}{l}5 \\
I \\
0 \cdot I\end{array}$ & $\begin{array}{l}0.070 \\
0.070 \\
0.091\end{array}$ & $\begin{array}{l}0.056 \\
0.210 \\
0.280\end{array}$ & $\begin{array}{l}0.056 \\
0.070 \\
0.280\end{array}$ \\
\hline L-Thialysine & $\begin{array}{l}5 \\
\text { I } \\
O \cdot I\end{array}$ & $\begin{array}{l}0.00 \\
0.105 \\
0.210\end{array}$ & $\begin{array}{l}0.280 \\
0.245 \\
0.280\end{array}$ & $\begin{array}{l}0.245 \\
0.245 \\
0.280\end{array}$ \\
\hline DL-Hydroxylysine & $\begin{array}{r}10 \\
3 \\
1\end{array}$ & $\begin{array}{l}0.105 \\
0.175 \\
0.245\end{array}$ & $\begin{array}{l}0.140 \\
0.280 \\
\text { ND }\end{array}$ & $\begin{array}{l}0.140 \\
0.280 \\
\text { ND }\end{array}$ \\
\hline L-Arginine & $\begin{array}{r}10 \\
5\end{array}$ & $\begin{array}{l}0.070 \\
0.210\end{array}$ & $\begin{array}{l}0 \cdot 210 \\
\mathrm{ND}\end{array}$ & $\begin{array}{l}\text { ND } \\
\text { ND }\end{array}$ \\
\hline L-Norleucine & $\begin{array}{r}10 \\
5\end{array}$ & $\begin{array}{l}0.210 \\
0.245\end{array}$ & $\begin{array}{l}0.280 \\
\text { ND }\end{array}$ & $\begin{array}{l}\text { ND } \\
\text { ND }\end{array}$ \\
\hline L-Norvaline & 10 & $\begin{array}{l}0.245 \\
\text { not de }\end{array}$ & 0.280 & ND \\
\hline
\end{tabular}

Table 2. Production and excretion of non-protein lysine by wild-type (x2180), thialysineresistant (AEC-RI) and hydroxylysine-resistant (OHL-IA) strains of S. cerevisiae

Cells were grown in medium supplemented with $\mathrm{DL}-2-a m i n o\left[\mathrm{I}-{ }^{14} \mathrm{C}\right]$ adipic acid. 'Intracellular' and 'extracellular' concentrations of $\left[{ }^{14} \mathrm{C}\right]$ lysine and 2 -amino $\left[\mathrm{I}-{ }^{14} \mathrm{C}\right]$ adipic acid were determined after growth for $48 \mathrm{~h}$.

\begin{tabular}{|c|c|c|c|c|}
\hline \multirow[b]{2}{*}{ Strain } & \multicolumn{2}{|c|}{$\begin{array}{l}\text { 2-Amino }\left[\mathrm{I}^{14} \mathrm{C}\right] \text { adipate } \\
\text { remaining after growth } \\
\text { (counts } / \mathrm{IO}^{7} \text { cells) }\end{array}$} & \multicolumn{2}{|c|}{$\begin{array}{c}{\left[{ }^{14} \mathrm{C}\right] \text { Lysine }} \\
\text { (counts } / \mathrm{IO}^{7} \text { cells) }\end{array}$} \\
\hline & Extracellular & Intracellular & Extracellular & Intracellular \\
\hline $\mathrm{X} 2 \mathrm{I} 80$ & 5824 & $204 \mathrm{I}$ & 5 I I & I 8 I \\
\hline AEC-R I & 5745 & 107 & I9I I & I 8 \\
\hline OHL-I A & 5301 & $225 \mathrm{I}$ & 655 & 198 \\
\hline
\end{tabular}

adipic acid from all three cultures was about the same. Excretion of excess lysine by the thialysine-resistant strain was confirmed by the ability of the concentrated culture supernatant from AEC-RI to support growth of a lysine auxotroph (lysI3) of $S$. cerevisiae.

Activities of homocitrate synthase were compared in strains X2I80, AEC-RI, and in a lysine auxotroph lacking saccharopine reductase, lys 3 (Bhattacharjee \& Sinha, 1972) after growth with or without various additions to the minimal medium. The synthase activity of auxotroph $l y s \mathrm{I} 3$ grown in minimal medium supplemented with L-lysine $\left(20 \mu \mathrm{g} \mathrm{ml}^{-1}\right)$ was considered as $100 \%$. L-Lysine $\left(\mathrm{IO}^{-4} \mathrm{M}\right)$ or L-thialysine $\left(\mathrm{IO}^{-5} \mathrm{M}\right)$ repressed the biosynthesis of homocitrate synthase in strain X2180 by $80 \%$ and in AEC-RI by $50 \%$.

L-Lysine and DL-hydroxylysine inhibit both homocitrate synthases and exert noncoordinate repression of the enzymes of lysine biosynthesis including one of the two homocitrate synthases of $S$. cerevisiae (Sinha et al., I97I; Tucci \& Ceci, 1972). We propose a 
similar mechanism for the action of L-thialysine, and this would explain the inhibition of growth of wild-type $S$. cerevisiae by L-thialysine. Mutation in strain AEC-RI for resistance to thialysine appears to have a pleiotropic effect; causing excretion of lysine, impairment of feedback inhibition and repression of homocitrate synthase. The results in this paper do not show whether one or both homocitrate synthases of AEC-RI are insensitive to feedback inhibition and resistant to repression by L-lysine and L-thialysine. Mutant OHL-I A does not excrete any lysine and is somewhat less resistant than mutant AEC-RI to inhibition. The precise nature of the mutations involved in strains AEC-RI and OHL-IA and whether they affect structural or regulatory genes for homocitrate synthase are not known.

This research was supported by NSF grants GB28558X, BMS 75-07208 and the faculty research committee, Miami University.

\section{REFERENCES}

BhattacharJeE, J. K. \& TucCI, A. F. (1969). Relationship of glutaric acid to the homicitric acid pathway of biosynthesis of lysine in yeast. Journal of Biological Chemistry 244, 1417-1423.

BhattacharJeE, J. K. \& SinHA, A. K. (1972). Relationship among the genes, enzymes, and intermediates of the biosynthetic pathway of lysine in Saccharomyces. Molecular and General Genetics 115, 26-30.

FuJIOKA, M. \& NAKATANI, Y. (1972). Saccharopine dehydrogenase: Interaction with substrate analogs. European Journal of Biochemistry 25, 30I-307.

Gornall, A. G., Bardawill, C. J. \& David, M. M. (1949). Determination of serum proteins by means of the biuret reaction. Journal of Biological Chemistry $\mathbf{1 7 7}, 75 \mathrm{I}-766$.

HogG, R. W. \& BRoQUIST, H. P. (1968). Homocitrate formation in Neurospora crassa. Journal of Biological Chemistry 243, 1839-1 845.

Kurtz, M. \& BhattacharJeE, J. K. (I975). Biosynthesis of lysine in Rhodotorula glutinis: Role of pipecolic acid. Journal of General Microbiology 86, I03-I 10.

SinHa, A. K. \& BhattacharJeE, J. K. (1970). Control of a lysine biosynthetic step by two unlinked genes of Saccharomyces. Biochemical and Biophysical Research Communications 39, I 205-1 210.

Sinha, A. K., KURTZ, M. \& BhatTACHARJEE, J. K. (I97I). Effect of hydroxylysine on the biosynthesis of lysine in Saccharomyces. Journal of Bacteriology 108, 71 5-719.

TuCCI, A. F. \& CECI, L. N. (1972). Homocitrate synthase from yeast. Archives of Biochemistry and Biophysics 153, 742-750.

Wieland, O., Weiss, L. \& Eger-Neufeldt, I. (1964). Inhibition of enzymatic citric acid synthesis by longchained acetyl-thioesters of coenzyme A. Biochemische Zeitschrift 339, 50I-5I3. 